\title{
Seasonal movements of American lobsters in southern Gulf of Maine coastal waters: patterns, environmental triggers, and implications for larval release
}

\author{
Jason S. Goldstein*, Winsor H. Watson III \\ University of New Hampshire, Department of Biological Sciences, 46 College Road, Durham, New Hampshire 03824, USA
}

\begin{abstract}
American lobsters Homarus americanus are known to move offshore during the fallto-winter transition and inshore, into shallower, warmer water in the spring and summer. To determine whether all types of lobsters in New Hampshire coastal waters exhibit this movement pattern, we fitted 45 lobsters (ovigerous and non-ovigerous females, and males) with ultrasonic transmitters and tracked their movements over 3 successive seasons from 2006 to 2009. The major goals of this study were to determine (1) if ovigerous females express different seasonal movement patterns than males or non-ovigerous females; (2) what environmental cues might trigger offshore movements in the fall; and (3) the location of ovigerous females when their eggs hatch in the spring-summer. Most lobsters (82\%) moved $>0.5 \mathrm{~km}$, whereas the rest remained close to their original release location. Of the lobsters that moved, $51 \%$ moved $<5 \mathrm{~km}, 19 \%$ moved $5-10 \mathrm{~km}$, and $30 \%$ moved $>10 \mathrm{~km}$. There were no significant differences in the seasonal movements of ovigerous females compared with non-ovigerous females, but females as a group moved significantly farther than males. The ovigerous lobsters that moved offshore tended to remain there until the time when their eggs most likely hatched. In conclusion, the seasonal movements of ovigerous lobsters in coastal waters significantly influence the location and timing of larval hatch and, ultimately, settlement.
\end{abstract}

KEY WORDS: Acoustic telemetry · Seasonal movements · Ovigerous lobsters · Larval dispersal • Homarus americanus

Resale or republication not permitted without written consent of the publisher

\section{INTRODUCTION}

Seasonal movements in marine decapod crustaceans appear to serve a variety of purposes including: (1) acquiring food and shelter; (2) avoiding suboptimal habitats and environmental perturbations (e.g. extreme temperatures, turbulence); (3) enhancing growth and development by moving to areas with optimal temperatures; and (4) improving the dispersal of progeny (e.g. eggs and larvae) (Herrnkind 1980, Lawton \& Lavalli 1995, Pittman \& McAlpine 2003, Bowler \& Benton 2005, Nathan 2008). American lobsters Homarus americanus exhibit well documented daily and seasonal movements and, while most lobster movements are considered local in nature (5-10 km), long-distance movements have also been reported (Cooper \& Uzmann 1980, Fogarty et al. 1980, Haakonsen \& Anoruo 1994, Lawton \& Lavalli 1995, Bowlby et al. 2007, Scopel et al. 2009). On a seasonal basis, lobsters tend to move offshore into deeper water during the transition from fall to winter when nearshore water temperatures drop, followed by a return to shallower water in the spring when nearshore waters warm (Campbell 1986, Campbell \& Stasko 1986, Haakonsen \& Anoruo 1994, also see reviews in Lawton \& Lavalli 1995, Childress \& Jury 2006). Lobsters can detect small changes in water temperature (Jury \& Watson 2000), 
and respond both behaviorally (e.g. movement to areas of preferred water temperatures; Crossin et al. 1998, Jury \& Watson 2000) and physiologically (e.g. changes in heart rate; Worden et al. 2006). Therefore, seasonal changes in water temperature likely influence the movements and distribution of lobsters (Jury \& Watson 2013).

One hypothesis to explain seasonal movements of lobsters is the considerable number of degree-days they gain by moving. This gain, in turn, enhances growth rate and modulates other temperaturedependent processes such as ovary maturation and egg development (see review by Waddy \& Aiken 1995). For ovigerous lobsters, increased water temperatures also enhance egg development rate (Templeman 1940, Perkins 1972, Talbot \& Helluy 1995), whereas temperatures $<12^{\circ} \mathrm{C}$ may inhibit larval survivorship (MacKenzie 1988, Annis et al. 2007). Therefore, while all lobsters might benefit from moving to gain degree-days, the influence of water temperature on embryonic development and larval survivorship may preferentially favor movement in ovigerous female lobsters over non-ovigerous females or males. One of the goals of this study was to test this hypothesis.

Several studies demonstrate seasonal movement patterns in ovigerous lobsters similar to those in other lobsters (Campbell 1986, Harding \& Trites 1988, Lawton \& Lavalli 1995, Robichaud \& Campbell 1995, Cowan et al. 2007). However, despite general acceptance of offshore movement of lobsters in the fall and inshore in the spring, few published examples of this behavior in individual animals exist. For example, Cowan et al. (2007) fitted animals with ultrasonic tags and tracked them for months, but the transmitters did not last long enough to determine whether lobsters that moved offshore in fall returned in summer. This information is vital because the location of females when their eggs hatch could strongly influence the fate of their larvae. Therefore, one of the goals of this study was to test whether ovigerous females that move away from the coast in the fall return to inshore waters before their eggs hatch.

Other species of lobsters, and some crabs, also exhibit shallow to deep-water movements in the fall, and these movements often correlate with changes in water temperature and disturbances resulting from fall storms (Kanciruk \& Herrnkind 1978, Spanier et al. 1988, Gonzalez-Gurriaran et al. 2002, Stone \& O'Clair 2002). Ennis (1984) observed that American lobsters in a Newfoundland bay tended to move to deeper waters in response to increased storm turbulence and the breakdown of the thermocline in the fall, and Jury et al. (1994) showed that American lobsters tended to move towards colder, higher saline, deeper waters in an estuarine system following a hurricane. Laboratory studies demonstrate that these lobsters can detect subtle differences in water temperature (Jury \& Watson 2000) and salinity (Dufort et al. 2001), and that they avoid hyposaline water, as well as adversely high or low temperatures (Reynolds \& Casterlin 1979, Jury et al. 1994, Crossin et al. 1998). Thus, the third goal of this study was to test the hypothesis that a combination of seasonal drops in water temperature and increased turbulence resulting from fall storms trigger offshore movements of American lobsters along the New Hampshire coast during the fall-to-winter transition.

To test these aforementioned hypotheses, we tracked 45 American lobsters (non-ovigerous and ovigerous females) for $\sim 9-10$ mo (SeptemberAugust) in the period 2006-2009, using a variety of ultrasonic telemetry techniques. The data obtained were then used to determine if: (1) the movements of ovigerous females differed from other categories of lobsters; (2) ovigerous females returned inshore before their eggs hatched in the late spring/early summer; and (3) offshore movements of lobsters in the fall coincided with fall storms and rapidly cooling water temperatures.

\section{MATERIALS AND METHODS}

\section{Study site}

All tracking of American lobsters Homarus americanus fitted with ultrasonic tags took place in coastal New Hampshire (NH), Southern Maine, and northern Massachusetts, USA between fall 2006 and summer 2009 (3 field seasons in total; Fig. 1). All lobsters were captured in standard lobster traps, and released in a small cove just off New Castle Island, $\mathrm{NH}$, near the mouth of the Piscataqua River $\left(43^{\circ} 04.912^{\prime} \mathrm{N}_{\text {; }}\right.$ $\left.70^{\circ} 42.456^{\prime} \mathrm{W}\right)$. The local benthic habitats at the tagging and release location were comparable to much of coastal $\mathrm{NH}$ and included a prominent shallow rocky reef complex (2-8 $\mathrm{m}$ depth) surrounded by a heterogeneous mixture of sand and fine sediment flats interspersed with patchy eelgrass Zostera marina beds. A deeper channel (18-20 m) was located slightly offshore (east) and adjacent to the reef. Bottom water temperatures, monitored with HOBO temperature data loggers (model UA-002-64, Onset Computer) ranged from $2-18^{\circ} \mathrm{C}$ over the course of the study. Current speeds and directions measured at 


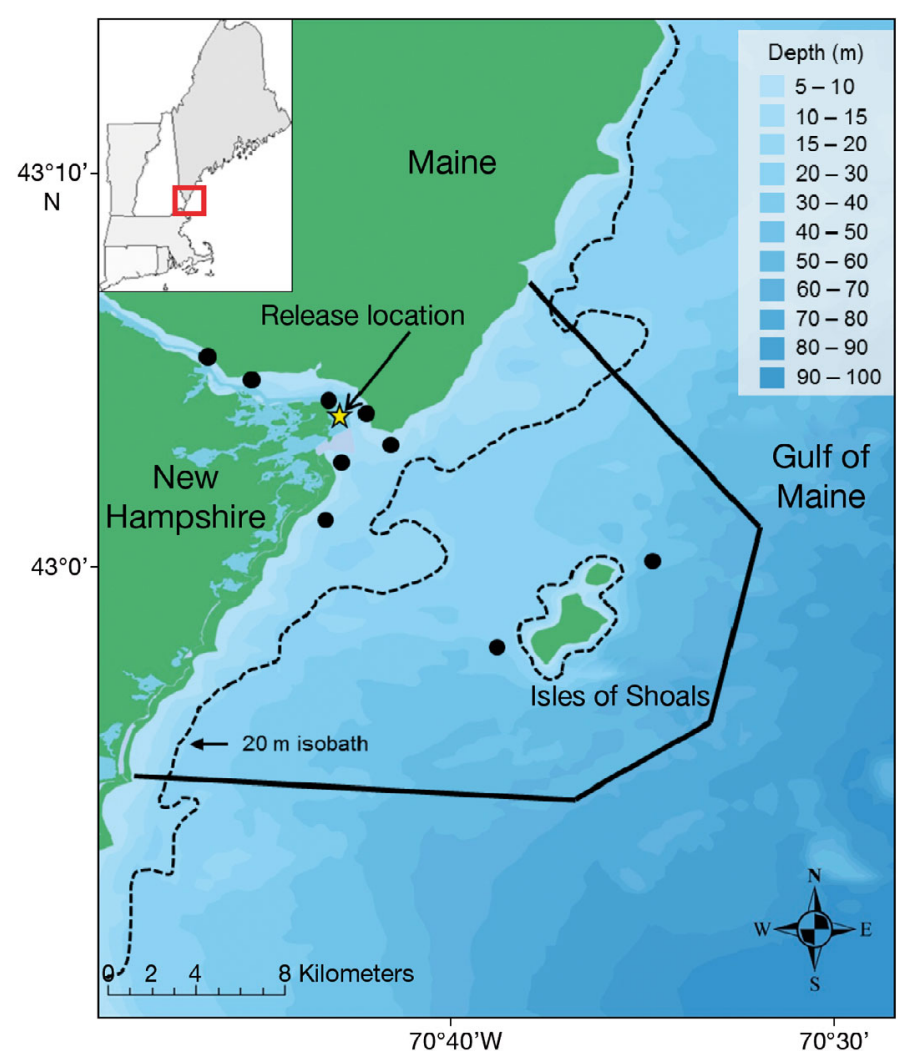

Fig. 1. Study area, and the capture/release location (star) for lobsters tagged and tracked in 2006-2009 as well as positions of telemetry receiver/loggers (VR2s) (black circles). The dashed line indicates the approximate location of the $20 \mathrm{~m}$ isobath, used to delineate inshore from offshore areas, whereas the solid line outlines the area covered $\left(\sim 375 \mathrm{~km}^{2}\right)$ using manual tracking methods
(Stage C, Waddy \& Aiken 1992) were used for this study because, unlike many sphyrion tags, ultrasonic transmitters are typically lost during molting. For most ovigerous lobsters, we removed a small sample $(10-15)$ of eggs from the abdomen and placed it in a $2.0 \mathrm{ml}$ tube with a $4 \%$ formalin-seawater fixative for later determination of developmental stage according to the methods described in Helluy \& Beltz (1991).

Lobsters were fitted with VEMCO V13-1L coded tags $(69 \mathrm{kHz}, 13 \mathrm{~mm}$ diameter, $36 \mathrm{~mm}$ long, $6 \mathrm{~g}$ in water, estimated battery life $\sim 320$ d, VEMCOAMIRIX Systems). Tags were coded with random inter-ping intervals between 60 and $180 \mathrm{~s}$, which reduced the probability of tags pinging simultaneously and thus going undetected. Animals were also tagged with small (19 $\mathrm{mm}$ diameter) vinyl-laminated disc tags (Floy Tag) containing contact information and a message requesting lobstermen to either keep or release lobsters, depending on date of capture. A subset of lobsters (ovigerous, $\mathrm{n}=10$ ) were also fitted with HOBO Tidbit temperature loggers (Onset Computer) that recorded temperature every $30 \mathrm{~min}$ and could be downloaded using a PC-based software package (HOBOware Pro v. 3.0) upon recapture. Ultrasonic tags were secured by gluing them inside a piece of Tygon ${ }^{\circledR}$ tubing and then attaching the tubing to each lobster using a cable-tie fastened between the second and third pair of walking legs (Fig. 2; Golet et al. 2006, Scopel et al. 2009). The disc tag and temperature logger (where applicable) were then cable-tied onto the main transmitter harness using smaller cable-ties. Finally, a small amount of

$1 \mathrm{~m}$ from the bottom in the release location ranged from $0.03-28.9 \mathrm{~cm} \mathrm{~s}^{-1}$ throughout all tidal cycles (Golet et al. 2006). For the purposes of this study, we considered areas $<5 \mathrm{~km}$ from shore as inshore, corresponding to a depth range of $5-20 \mathrm{~m}$ (mean $=8 \mathrm{~m})$ and areas $>5 \mathrm{~km}$ from shore at depths $>20 \mathrm{~m}$ (Fig. 1) as offshore. The exception to these designations was the Isles of Shoals area ( $<5 \mathrm{~km}$ from shore, but with steep drop-offs and $>5 \mathrm{~km}$ from the tagging location), which we considered offshore.

\section{Tagging protocol}

Lobsters were caught using standard baited lobster traps. Upon capture, lobster size (carapace length, CL) and sex were recorded along with molt stage. Only postmolt lobsters

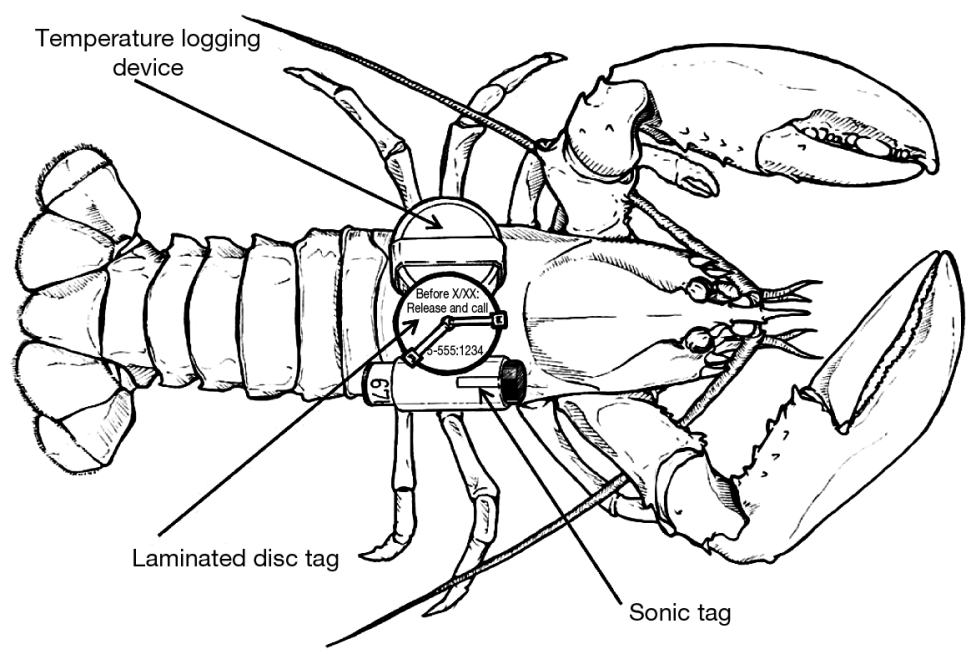

Fig. 2. Homarus americanus. Arrangement of the instrument backpack attached to lobsters. All animals were fitted with an ultrasonic transmitter and laminated disc tag; some were also equipped with a temperature logger 


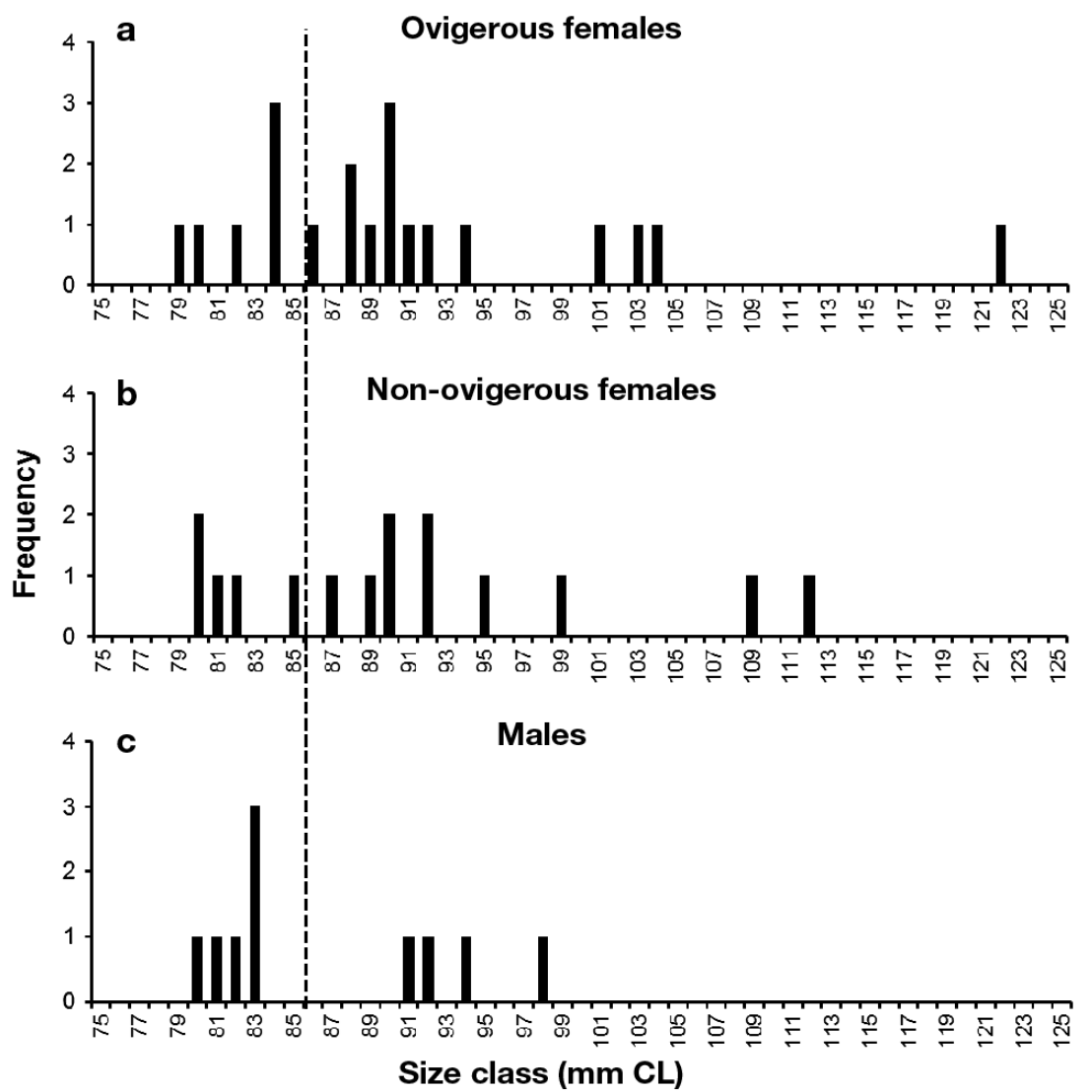

Fig. 3. Homarus americanus. Size-frequency distribution for all lobsters tracked in 2006-2009. Lobster categories included (a) ovigerous females ( $\mathrm{n}=$ $\left.20, \mathrm{CL}_{\text {mean }}=87.7 \pm 2.3 \mathrm{~mm}\right)$, (b) non-ovigerous females $\left(\mathrm{n}=15, \mathrm{CL}_{\text {mean }}=90.9 \pm\right.$ $2.5 \mathrm{~mm})$, and (c) males $\left(\mathrm{n}=10, \mathrm{CL}_{\text {mean }}=86.7 \pm 2.0 \mathrm{~mm}\right)$. In some cases, during data analyses, we distinguished between large and small lobsters (delineated by the dotted line) based on maturity schedules from Little \& Watson (2003)
Although we originally tagged a total of 53 lobsters, only 45 lobsters (18 females and 0 males in 2006, 12 females and 6 males in 2007, 5 females and 4 males in 2008, n = 10 ovigerous animals with temperature loggers; Fig. 3) yielded sufficient data to include in our final analyses. Of the 8 lobsters we excluded, 3 died, 3 were not detected after $<20$ d (most likely because they moved out of the study area), and 2 molted (one was located SCUBA diving near the tagging site, the other molt was found in a lobster trap). Most lobsters were fitted with transmitters in the late summer and early fall and tracked throughout the winter and the following spring and early summer. Although one of our primary goals was to document any differences between the movements expressed by ovigerous females and non-ovigerous lobsters (males and females), we tagged more ovigerous lobsters for 2 reasons. First, movement data obtained from ovigerous lobsters were also part of a companion egg development study (Goldstein \& Watson 2015). Second, ovigerous lobsters caught by fishermen must be released, so they remain at-large longer than those without eggs. cyanoacrylate glue and $1.5 \mathrm{~cm}$ duct-tape squares were fastened from the cable-tie to the carapace to prevent the backpack from slipping. The entire tagging process took $\sim 3-5 \mathrm{~min}$. After tagging, lobsters were placed into standard single-parlor lobster traps with doors and vent removed to facilitate escape. The traps were lowered to the bottom, where the lobsters gradually left the traps and took up residence in the same area (verified by tracking with a high resolution VRAP telemetry system, VEMCO-AMIRIX Systems; Golet et al. 2006, Scopel et al. 2009). This approach reduced the tendency of lobsters to move large distances after handling. While we did not directly examine the influence of transmitter backpacks on lobster behavior and locomotion, distances traveled by tagged and untagged lobsters in both field and laboratory settings suggested no significant impact (Jepsen et al. 2002, Golet et al. 2006, Scopel et al. 2009).

\section{Ultrasonic telemetry}

Lobsters were tracked using 3 types of commercially available hydrophone-receiver instruments. First, 7 fixed underwater acoustic receivers (VR2s) that function as low resolution, high-coverage ( 400-500 m radius effective range) 'gateways' were moored along the NH coast and out to the Isles of Shoals (see Fig. 1). These self-contained units detected the presence of transmitters and logged the time and transmitter ID. The placement of the VR2s was based on previous studies in the area (Scopel et al. 2009), as well as prominent geomorphic features (channels, islands, sandy flats) that could influence movements. Second, a mobile acoustic receiver (VR100), connected to an omni-directional hydrophone, was periodically towed behind a research boat on a custom-made harness at a depth of 3-4 m. This receiver provided medium-scale resolution 
(within 20-100 m of a tag) and enabled us to locate animals in virtually any location in the study area. Finally, a high resolution fixed array radio-acoustic positioning system (VRAP), which utilizes a triangulation algorithm to locate animals within its range, was deployed in the fall of 2006 to track lobster movements during the fall and winter to determine when lobsters initiated their offshore movements. The high resolution fixed array radio-acoustic positioning system (VRAP) was deployed in the fall of 2006 to track lobster movements during the fall and winter to determine when lobsters initiated their offshore movements. The VRAP system consisted of a 3-buoy array and a base station. The buoys were moored $\sim 150 \mathrm{~m}$ apart in an equilateral triangle and, when they detected transmissions, they radioed the data to a base station where software triangulated the position of each transmitter based on the signal arrival times at each buoy (resolution $\sim 1-3 \mathrm{~m}$ ). Technical details of this tracking system are found in Golet et al. (2006) and Watson \& Chabot (2010). All telemetry equipment and associated software was obtained from VEMCO-AMRIX Systems (www. vemco.com).

\section{Manual tracking}

Manual (VR100) tracking was conducted at weekly, or biweekly (wintertime) intervals, throughout the year and it took approximately 1 mo to cover the entire study area using this method (see Fig. 1). However, the positions of animals inshore, around the release location, and those that were near the VR2s, were obtained much more frequently (daily to weekly). Therefore, while daily and weekly data were available for some animals, seasonal movement trends were generally analyzed using monthly data. The accuracy and reliability of the manual (VR100) telemetry system were verified in 2 ways. First, a simple range test was conducted to determine the distance at which a particular tag could be detected (Webber 2009). A second test determined the most probable location of a lobster, given that the manual tracking system often logged multiple fixes for a single animal as the hydrophone was being towed past it. Data obtained using the VRAP system were used to ground-truth the actual position of a given lobster/transmitter, and this position was then compared to GPS locations obtained using the towed system. Averaging all the GPS coordinates obtained for a given lobster as the vessel passed by yielded a single GPS location that was within 10-15 m of the animal's actual position. In addition to data obtained using telemetry, we frequently received positional information (latitude/longitude or LORAN coordinates) from lobstermen who caught tagged lobsters and phoned or emailed us this information (per instructions on the disc tags). Informational flyers were distributed to lobster pounds, fishermen co-ops, and lobster wholesalers in the area to explain the details of the study to fishermen.

\section{Environmental data}

Daily water temperature data were acquired using a combination of HOBO pendant temperature loggers attached to the VR2s in fixed locations and HOBO Tidbit temperature loggers recovered from some of the recaptured lobsters. Wave height measurements, indicative of storm events, were obtained from ocean observation buoys for the fall of 2006. Wave heights were queried as daily averages and downloaded for selected time frames from the Gulf of Maine Ocean Observing database (GOMOOS; www. neracoos.org/gomoos) from 2 buoy locations: (1) NOAA CMAN IOSN3 (Isles of Shoals; $42^{\circ} 58.200^{\prime} \mathrm{N}$, $70^{\circ} 37.200^{\prime} \mathrm{W}$ ); and (2) Buoy B01 (Western Maine Shelf; $\left.42^{\circ} 10.850^{\prime} \mathrm{N}, 70^{\circ} 25.667^{\prime} \mathrm{W}\right)$. Relationships between lobster movements from inshore to offshore locations, temperature, and wave heights were analyzed per individual lobster using pairwise correlations in JMP v. 9.0.3 (SAS Institute).

\section{Data processing and analysis}

Lobster locations were plotted using the ArcGIS v.9.3 software package (ESRI). If more than one position was obtained on a given day during manual tracking or from the VRAP system, GPS fixes were averaged to yield a single location per day. The positions of lobsters detected by VR2s were considered to be the location of the VR2 unit.

To calculate the distance a given animal moved from one season to the next, we used the 2 points ( 1 from each season) that yielded the maximum distance traveled. The 3 seasonal time periods (4 mo each) chosen for our calculations were fall-winter (September 1 to December 31), winter-spring (January 1 to April 30) and spring-summer (May 1 to August 31). The partitioning of these seasons corresponded to periods when (1) temperatures were decreasing (fall-winter) and, based on previous studies, lobsters tended to move offshore (Lawton \& 


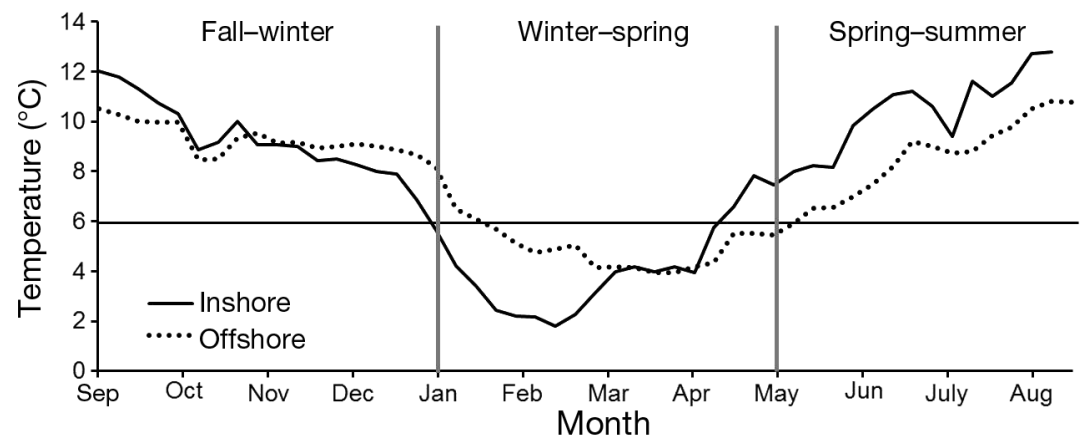

Fig. 4. Weekly temperature averages compiled over 3 field seasons (20062009) for representative inshore and offshore locations using in situ temperature (HOBO) loggers. The calendar year was partitioned into 3 distinct thermal time periods used to evaluate seasonal lobster movements. See 'Materials and methods' for details

Lavalli 1995); (2) temperatures fell $<6^{\circ} \mathrm{C}$, remained $<6^{\circ} \mathrm{C}$ (winter-spring), and lobsters tended to remain in one location; and (3) temperatures were increasing and lobsters generally became more active $\left(>6^{\circ} \mathrm{C}_{\text {; }}\right.$ spring-summer) (Fig. 4). If animals moved away from the coast, distances were recorded as positive values, whereas movements towards the coast were recorded as negative. To calculate 'net' distances, we summed positive and negative values. Days-at-large (DAL) were calculated as the cumulative number of days from release to the last positional fix. For comparison of distances traveled by individual lobsters of different size categories (based on maturity schedules reported in Little \& Watson 2003), animals were grouped into 6 categories: large females $(86-120 \mathrm{~mm}$ $\left.\mathrm{CL}_{i} \mathrm{n}=10\right)$, small non-ovigerous females $(70-85 \mathrm{~mm}$ $\left.\mathrm{CL}_{i} \mathrm{n}=5\right)$, large ovigerous females $(\mathrm{n}=14)$, small ovigerous females $(\mathrm{n}=6)$, large males $(\mathrm{n}=4)$ and small males $(\mathrm{n}=6)$.

To establish when lobsters left the VRAP array (in 2006 only) we utilized the 'Playback' command module in the VEMCO software package (VRAP v.5.1.4), which allows playback and visualization of the tracking history for each tagged animal. For each individual, we noted the day of year on which the lobster left the VRAP array and moved offshore.

All movement analyses were conducted using the statistical software package JMP v.9.0.3. Directional data were analyzed from a Rayleigh's Z-test using Oriana (v.3.0) software (Kovach Computing Services). Data that did not meet parametric assumptions were analyzed using non-parametric Mann-Whitney $U$-tests. All means are given $\pm \mathrm{SE}$.

\section{RESULTS}

A total of 45 lobsters were tagged and successfully tracked between 2006 and 2008 (2006, $\mathrm{n}=18$; 2007, $\mathrm{n}=18 ; 2008, \mathrm{n}=9$; Table 1 ). The majority of these lobsters $(82 \%, \mathrm{n}=37)$ moved at least $0.5 \mathrm{~km}$, whereas the remainder remained in the same general area during the 9-10 mo tracking period. Of the lobsters that moved, $51 \%$ moved $<5 \mathrm{~km}, 19 \%$ moved $5-10 \mathrm{~km}$, and $30 \%$ moved $>10 \mathrm{~km}$.

\section{Days-at-large (DAL)}

Overall, all 45 lobsters were at-large for an average of $223.9 \pm 11.8 \mathrm{~d}$. However, at-large times for ovigerous females were longer $($ mean $=248.2 \pm 17.1)$ than for non-ovigerous females (mean $=220.9 \pm 19.7$ ), or males $($ mean $=180.0 \pm 24.1$; Fig. 5). This difference presumably resulted from the requirement that lobstermen release any captured ovigerous lobsters. Nevertheless, DAL did not differ significantly among the 3 lobster categories $\left(\right.$ ANOVA $_{i} F_{2,44}=2.69, \mathrm{p}=$ 0.081), nor in comparing DAL for large versus small lobsters, both within, and between, lobster categories ( 2 -factor ANOVA; $F_{5,44}=1.20, \mathrm{p}=0.326$ ). For example, small males (mean DAL $=161.5 \pm 32.0$ ) were not at-large significantly longer than large males (mean $=207.3 \pm 39.1)$, or either ovigerous or nonovigerous females (range $=217.2-251.1$ ) (Tukey HSD; $\mathrm{q}=3.01, \mathrm{p}>0.05, \alpha=0.05$ ). Of the 37 lobsters $(82.2 \%)$ caught at least once by commercial fishermen and reported, 8 were caught more than once.

\section{Distance traveled}

The maximum absolute distances traveled by the 3 categories of lobsters differed significantly (ANOVA; $F=3.43_{2,44}, \mathrm{MS}=130.5, \mathrm{p}=0.041$; Fig. 6). Ovigerous lobsters moved the farthest $(7.44 \pm 1.38 \mathrm{~km})$, whereas males moved the least $(1.29 \pm 1.95 \mathrm{~km})$. The mean absolute distance traveled by ovigerous females differed significantly from the mean distance moved by males, but not from non-ovigerous females (Tukey HSD; $\mathrm{q}=2.42, \mathrm{p}<0.05$; Fig. 6). Distances traveled by lobsters differed significantly among seasons 
Table 1. Inventory of all Homarus americanus tagged and tracked $\left(\mathrm{n}_{\text {total }}=45\right)$ in each season: $2006(\mathrm{n}=18), 2007(\mathrm{n}=$ 18), and 2008 ( $\mathrm{n}=9$ ). Categories include ovigerous females, $\mathrm{F}(\mathrm{o})$, non-ovigerous females $(\mathrm{F})$, and males $(\mathrm{M})$. CL: carapace length. Days-at-large (DAL) were calculated as the cumulative number of days from release to the last positional fix. Max. Dist. is the maximum absolute distance traveled. Egg assessment is based on the Perkins Eye Index (Perkins 1972) and calculated for a subset of eggs. Egg dev.\% is the percentage of ovigerous females with eggs. Eggs with $0 \%$ development lacked discernible eyespots, and were not measured

\begin{tabular}{|c|c|c|c|c|c|c|}
\hline Year & Sex & $\begin{array}{c}\mathrm{CL} \\
(\mathrm{mm})\end{array}$ & $\begin{array}{l}\text { Date tagged } \\
\text { (mm/dd/yy) }\end{array}$ & DAL & $\begin{array}{l}\text { Max. dist. } \\
(\mathrm{km})\end{array}$ & $\begin{array}{c}\text { Egg } \\
\text { dev. (\%) }\end{array}$ \\
\hline \multicolumn{7}{|l|}{2006} \\
\hline & $\mathrm{F}(\mathrm{o})$ & 79 & $12 / 06 / 06$ & 211 & 7.73 & 62 \\
\hline & $\mathrm{F}(\mathrm{o})$ & 82 & $10 / 03 / 06$ & 216 & 0.28 & 38 \\
\hline & $\mathrm{F}(\mathrm{o})$ & 84 & 09/22/06 & 315 & 11.35 & 58 \\
\hline & $\mathrm{F}(\mathrm{o})$ & 84 & $11 / 02 / 06$ & 206 & 19.59 & 52 \\
\hline & $\mathrm{F}(\mathrm{o})$ & 86 & 08/30/06 & 250 & 20.73 & 0 \\
\hline & $\mathrm{F}(\mathrm{o})$ & 88 & 09/26/06 & 99 & 0.54 & 0 \\
\hline & $\mathrm{F}(\mathrm{o})$ & 89 & 09/19/06 & 370 & 1.65 & 0 \\
\hline & $\mathrm{F}(\mathrm{o})$ & 90 & 09/22/06 & 296 & 7.40 & 34 \\
\hline & $\mathrm{F}(\mathrm{o})$ & 103 & $10 / 26 / 06$ & 336 & 5.90 & 43 \\
\hline & $\mathrm{F}(\mathrm{o})$ & 104 & $10 / 04 / 06$ & 309 & 14.44 & 0 \\
\hline & $\mathrm{F}(\mathrm{o})$ & 122 & 09/19/06 & 345 & 11.72 & 0 \\
\hline & $\mathrm{F}$ & 82 & $11 / 09 / 06$ & 264 & 12.49 & \\
\hline & $\mathrm{F}$ & 87 & $11 / 02 / 06$ & 180 & 0.97 & \\
\hline & $\mathrm{F}$ & 92 & 09/26/06 & 217 & 2.64 & \\
\hline & $\mathrm{F}$ & 95 & 09/29/06 & 124 & 21.82 & \\
\hline & $\mathrm{F}$ & 99 & 09/29/06 & 220 & 1.98 & \\
\hline & $\mathrm{F}$ & 109 & 09/26/06 & 223 & 9.20 & \\
\hline & $\mathrm{F}$ & 112 & $10 / 13 / 06$ & 206 & 5.80 & \\
\hline \multicolumn{7}{|l|}{2007} \\
\hline & $\mathrm{F}(\mathrm{o})$ & 90 & $10 / 26 / 07$ & 250 & 15.07 & 30 \\
\hline & $\mathrm{F}(\mathrm{o})$ & 90 & $10 / 16 / 07$ & 252 & 3.57 & 15 \\
\hline & $\mathrm{F}(\mathrm{o})$ & 91 & $10 / 22 / 07$ & 260 & 10.05 & 12 \\
\hline & $\mathrm{F}(\mathrm{o})$ & 101 & $10 / 16 / 07$ & 204 & 10.79 & \\
\hline & $\mathrm{F}(\mathrm{o})$ & 88 & $10 / 22 / 07$ & 34 & 0 & 23 \\
\hline & $\mathrm{F}(\mathrm{o})$ & 92 & $10 / 26 / 07$ & 313 & 0 & \\
\hline & $\mathrm{F}$ & 80 & $07 / 20 / 07$ & 152 & 5.20 & \\
\hline & $\mathrm{F}$ & 80 & $11 / 14 / 07$ & 241 & 4.03 & \\
\hline & $\mathrm{F}$ & 85 & $10 / 26 / 07$ & $\begin{array}{l}241 \\
229\end{array}$ & 22.54 & \\
\hline & $\mathrm{F}$ & 89 & $10 / 16 / 07$ & 340 & 1.15 & \\
\hline & $\mathrm{F}$ & 92 & $10 / 22 / 07$ & 247 & 3.17 & \\
\hline & $\mathrm{F}$ & 90 & $10 / 16 / 07$ & 239 & 0 & \\
\hline & $\mathrm{M}$ & 80 & $10 / 26 / 07$ & 221 & 0.31 & \\
\hline & $\mathrm{M}$ & 81 & $11 / 09 / 07$ & 207 & 3.41 & \\
\hline & $\mathrm{M}$ & 82 & $10 / 22 / 07$ & 39 & 0.62 & \\
\hline & $\mathrm{M}$ & 91 & $10 / 22 / 07$ & 58 & 0.50 & \\
\hline & $\mathrm{M}$ & 98 & $07 / 26 / 07$ & 267 & 0 & \\
\hline & $\mathrm{M}$ & 94 & $10 / 23 / 07$ & 196 & 2.81 & \\
\hline \multicolumn{7}{|l|}{2008} \\
\hline & $\mathrm{F}(\mathrm{o})$ & 80 & 09/30/08 & 225 & 0.58 & 8 \\
\hline & $\mathrm{F}(\mathrm{o})$ & 84 & 09/30/08 & 275 & 7.73 & 66 \\
\hline & $\mathrm{F}(\mathrm{o})$ & 94 & $10 / 14 / 08$ & 197 & 0 & \\
\hline & $\mathrm{F}$ & 81 & $09 / 30 / 08$ & 200 & 3.23 & \\
\hline & $\mathrm{F}$ & 90 & $10 / 14 / 08$ & 232 & 0.77 & \\
\hline & $\mathrm{M}$ & 83 & 09/30/08 & 250 & 1.20 & \\
\hline & $\mathrm{M}$ & 83 & 09/30/08 & 44 & 0 & \\
\hline & $\mathrm{M}$ & 83 & $10 / 14 / 08$ & 208 & 0.98 & \\
\hline & $\mathrm{M}$ & 92 & $10 / 14 / 08$ & 308 & 3.10 & \\
\hline
\end{tabular}

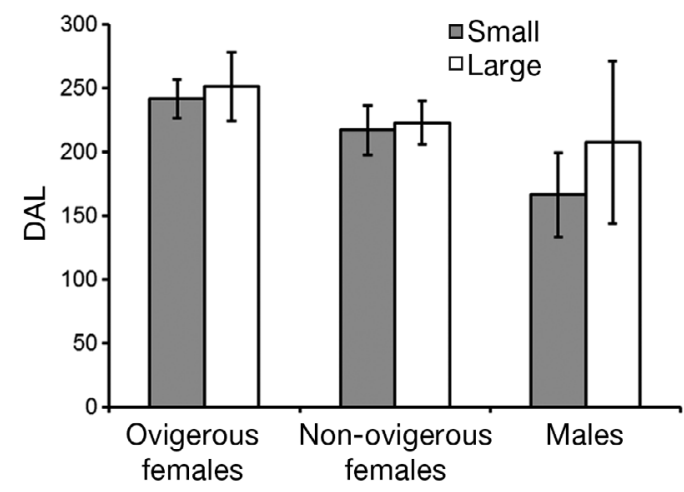

Fig. 5. Homarus americanus. Days-at-large (DAL) for large and small lobsters in each of the 3 categories of lobsters: ovigerous females $\left(\mathrm{n}_{\text {small }}=6, \mathrm{n}_{\text {large }}=14\right)$, non-ovigerous females $\left(\mathrm{n}_{\text {small }}=5, \mathrm{n}_{\text {large }}=10\right)$ and males $\left(\mathrm{n}_{\text {small }}=6, \mathrm{n}_{\text {large }}=4\right)$. Means are expressed $\pm \mathrm{SE}$

$\left(\right.$ ANOVA $; F_{2,84}=4.79, \mathrm{p}=0.011 ;$ Fig. 6 ), and distances traveled by lobster type differed slightly (ANOVA; $F_{2,44}=3.43, \mathrm{p}=0.051$ ), but not as a function of size (ANOVA; $F_{1,41}=0.46, \mathrm{p}=0.97$ ). Seasonal movements by 2 individual lobsters (an ovigerous and a nonovigerous female; Fig. 7) clearly illustrate the overall patterns expressed by most of the female lobsters tracked during this study. From fall to winter, both types of females moved significantly farther than males (Figs. 6 \& 8). Between January and April (winter-spring) lobsters moved very little (Figs. 6 \& 8). Then, in the late spring and early summer, ovigerous females moved a greater distance (mean $=2.55 \pm$ $0.66 \mathrm{~km})$ than non-ovigerous females $(1.56 \pm 0.64 \mathrm{~km})$ and males $(0.41 \pm 0.31 \mathrm{~km})$. However, these movements (particularly those of ovigerous lobsters) were not necessarily inshore, and those that moved inshore did so after the time of predicted hatch.

\section{Initiation of fall movements}

A total of 18 lobsters were tracked with the high resolution VRAP system in the fall of 2006 (11 ovigerous females, $\mathrm{CL}_{\text {mean }}=92.0 \pm 8.3 \mathrm{~mm}$ and 7 nonovigerous females, $\left.\mathrm{CL}_{\text {mean }}=95.6 \pm 11.7 \mathrm{~mm}\right)$. Most lobsters $(n=16)$ moved away from the VRAP array and were not detected again for $>24 \mathrm{~h}$, over a period of $21 \mathrm{~d}$ in October and November (mean day for departure $=$ November $1 ; 95 \% \mathrm{CI}=$ October 22 to November 11; Fig. 9). Lobsters tagged before October $5(\mathrm{n}=13,72.2 \%)$ expressed strong site fidelity, remaining near the tagging location for $39.5 \pm 6.6 \mathrm{~d}$ before moving offshore. By contrast, those tagged after October 5 remained in the area for significantly 


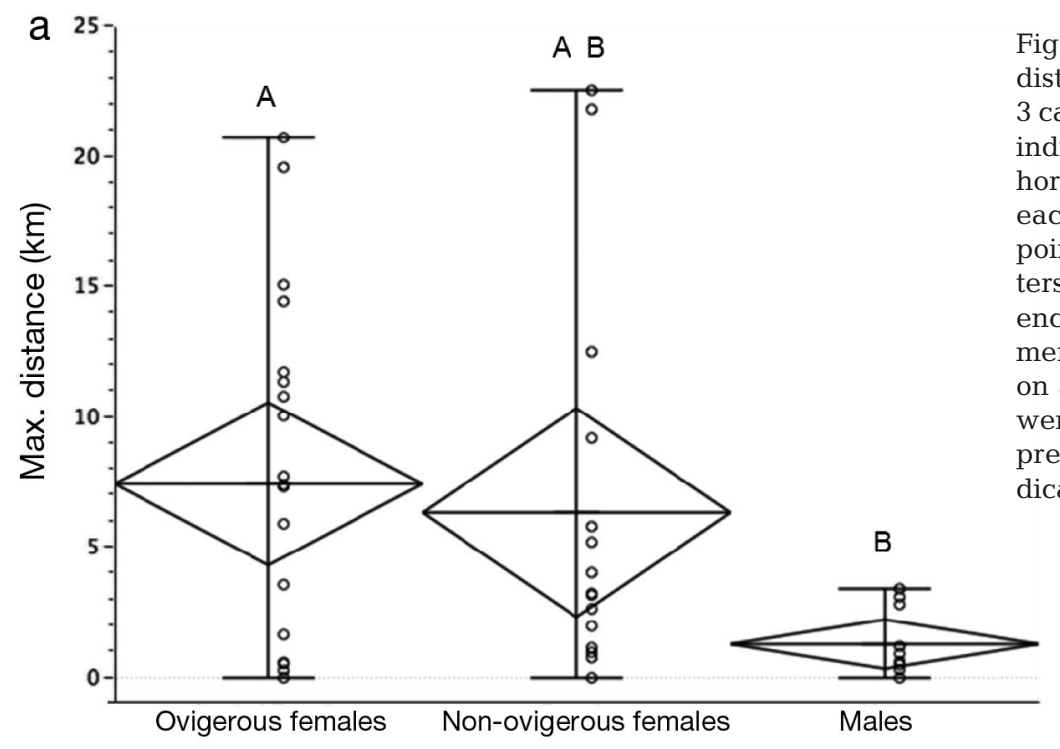

Fig. 6. Homarus americanus. (a) Maximum distance traveled by lobsters in each of the 3 categories (all sizes combined). Diamonds indicate $95 \%$ confidence intervals, with horizontal lines representing means for each group. Open circles represent data points for individual animals. Different letters above bars indicate significant differences ( $p$ < 0.05). (b) Net seasonal movements by lobsters in each category, based on animals that moved at least $0.5 \mathrm{~km}$ and were at large for at least $150 \mathrm{~d}$. Means expressed \pm SE. Shared letters above bars indicate no significant differences $(p>0.05)$
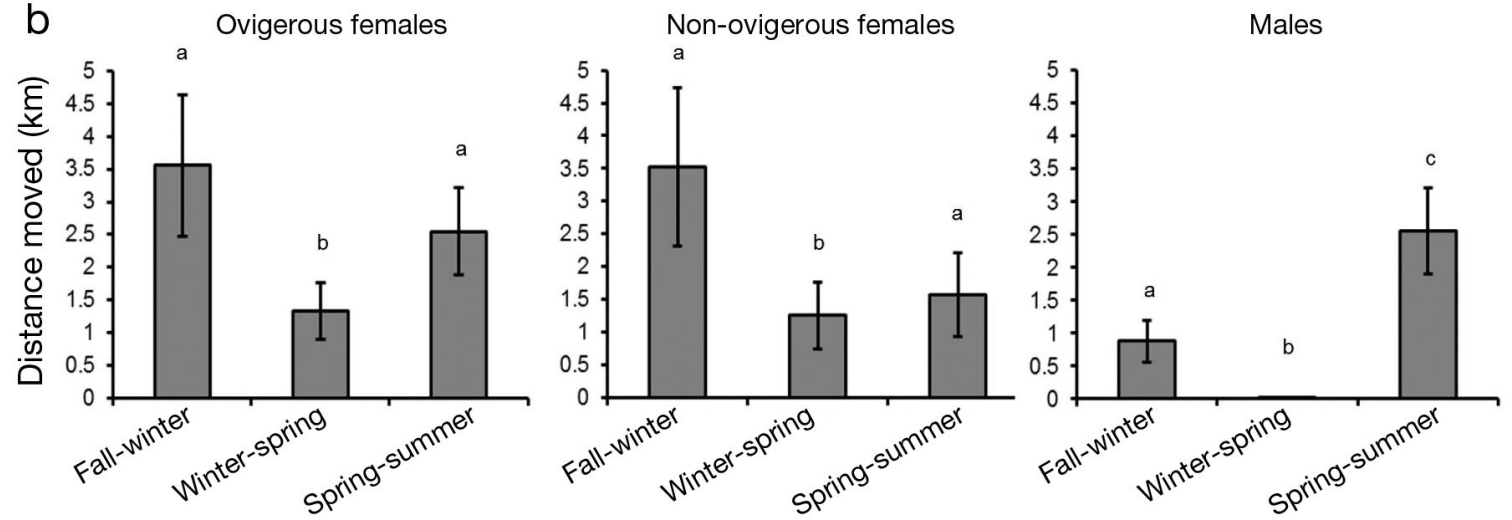

less time $\left(1.5 \pm 1.5 \mathrm{~d}_{;} t=3.781\right.$, df $\left.=17, \mathrm{p}=0.0015\right)$. Lobsters moving offshore initially headed SSE, with a mean vector of $159^{\circ}$ (Rayleigh test; $Z=25.35$, p < $0.001)$, placing them offshore and in deeper waters. However, we did not isolate a specific cue though data on other species we have examined suggests wave surge may be used (authors' unpubl. data).

\section{Environmental cues}

We hypothesized that declines in water temperature and storm events may both trigger fall offshore movements of lobsters. We monitored water temperatures and wave heights before, during, and after the period when lobsters left the tagging location (August-December of 2006) to assess the relationship between these environmental cues and lobster movements (Fig. 9). Water temperatures were generally stable during the time period prior to the initiation of offshore movements $\left(14.1 \pm 0.3^{\circ} \mathrm{C}_{i}\right.$ range $=$ $\left.12.9-15.7^{\circ} \mathrm{C}\right)$. However, starting in mid-October, when offshore movements began, temperature decreased significantly (from 14.1 to $10.3 \pm 0.5^{\circ} \mathrm{C}$, or a drop of $28.4 \%$, range $=9.0-12.8^{\circ} \mathrm{C}$; Mann-Whitney $U$-test; $\chi^{2}=12.9, \mathrm{df}=1, \mathrm{p}=0.0003$ ), compared with a similar time frame prior to the initiation of offshore movements (Fig. 9). Likewise, wave heights during these same 2 time periods also differed significantly (Mann-Whitney $U$-test; $\chi^{2}=5.8, \mathrm{df}=1, \mathrm{p}=0.0160$ ), averaging $0.8 \pm 0.08 \mathrm{~m}$ (range $=0.43-1.17 \mathrm{~m}$ ) before the initiation of offshore movements and $1.2 \pm 0.13 \mathrm{~m}$ $(\sim 36 \%$ increase; range $=0.58-1.77 \mathrm{~m})$ after offshore movements commenced (Fig. 9).

\section{Movements and egg development}

During 2006-2009, we tracked 17 ovigerous females carrying eggs that were partially developed $(25.9 \pm 6.0 \%$, range $=0-66 \%)$ when the females were first tagged. Distance traveled by lobsters was 

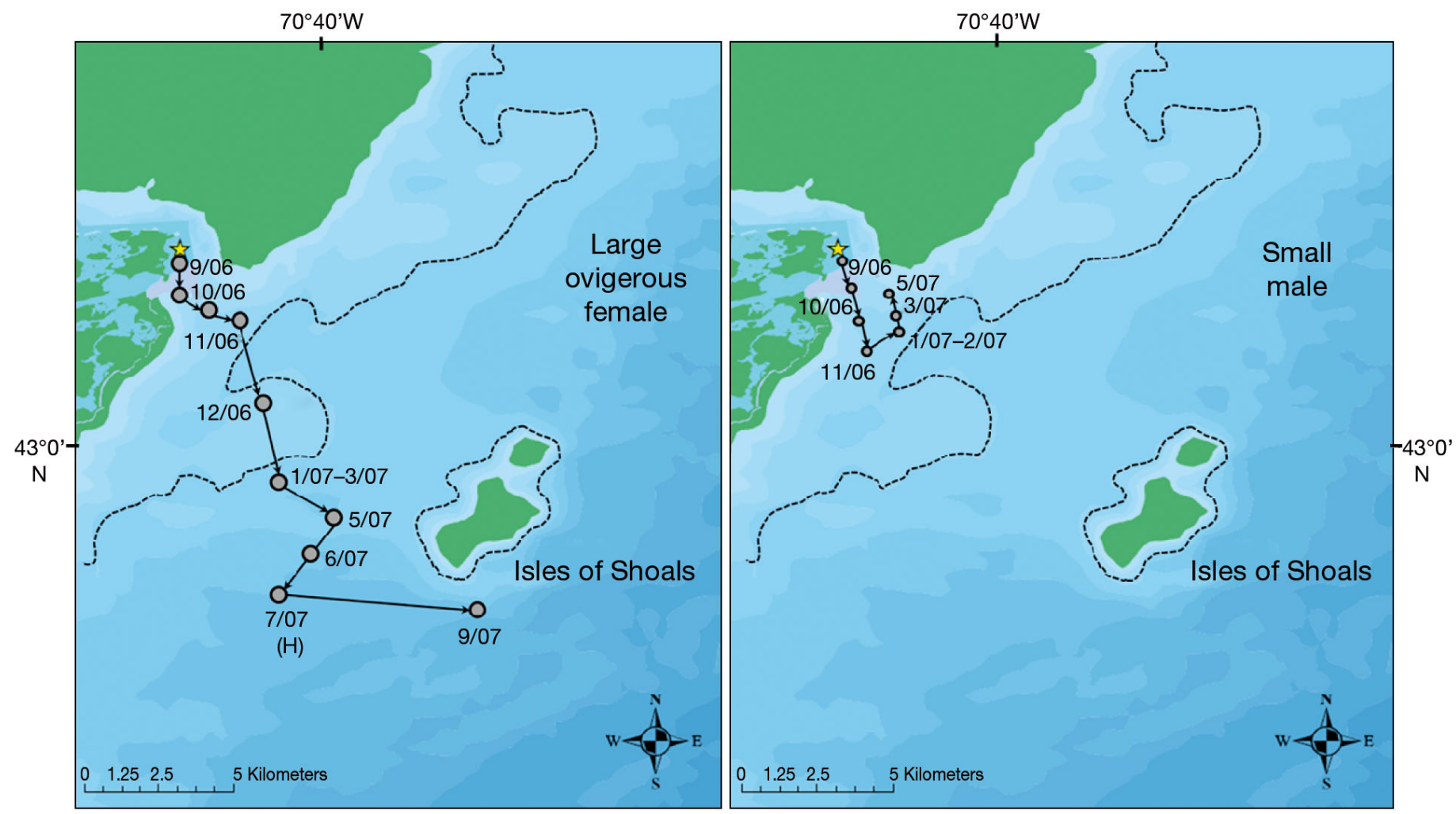

Fig. 7. Homarus americanus. Seasonal movements of a large ovigerous female $(\mathrm{CL}=90)$ and a small male lobster $(\mathrm{CL}=82)$ in 2006-2007. The track of the large ovigerous female is fairly typical for this group, characterized by large rapid offshore movements in the fall, a more stationary period in the winter months, followed by some additional movements after the predicted hatching date $(\mathrm{H})$. Note that this lobster and other ovigerous females did not return inshore in the early summer, and larvae were therefore likely released offshore. In contrast, most males (large and small) tracked in this study remained exclusively within inshore waters. Other details as in Fig. 1

unrelated to the initial stage of the eggs (early- vs. late-stage) they were carrying $(\mathrm{r}=0.24$; Spearman $\rho=0.26$ ). We also analyzed the thermal histories of 6 ovigerous lobsters with attached temperature loggers that we tracked in the fall of 2006 and successfully re-captured. Of these 6 individuals, 2 remained inshore, whereas 4 moved offshore in the fall. The predicted hatch time for the eggs carried by each lobster was determined from (1) recaptures and reports by commercial fishermen and (2) calculations of egg development based on starting egg stage values, ambient water temperatures recorded by our in situ temperature loggers attached to the lobsters, and the use of a modified Perkin's (1972) eye index (PEI) model (Goldstein 2012). Based on the temperature regimes these ovigerous females experienced while we tracked them, we predicted that the eggs carried by inshore lobsters hatched between July 10 and July 27 (average inshore temperature $=10.8^{\circ} \mathrm{C}$ ), whereas those carried by lobsters that moved offshore hatched from August 1 to August 20 (average offshore temperature $=10.4^{\circ} \mathrm{C}$ ).

\section{DISCUSSION}

By combining 3 different ultrasonic telemetry techniques, we documented both small-scale excursions of American lobsters Homarus americanus in New Hampshire coastal waters as they initiated offshore movements in the fall, as well as larger-scale, inshore-offshore and offshore-inshore, seasonal movements. Although the majority of ovigerous lobsters $(60 \%)$ we tracked moved offshore for the winter, so did $46 \%$ of all the other adult lobsters in our study, regardless of their sex or reproductive status. A combination of rapidly cooling waters and increased turbulence caused by fall storms appear to trigger these offshore movements in the fall. Taken together, these data suggest that offshore movements are likely adaptive for all types of lobsters, and not just those carrying eggs. Moving offshore may offer lobsters a more stable (and less variable) thermal habitat during the colder months when they tend to be less active and require less food. This pattern has been noted in the congener, H. gammarus, 

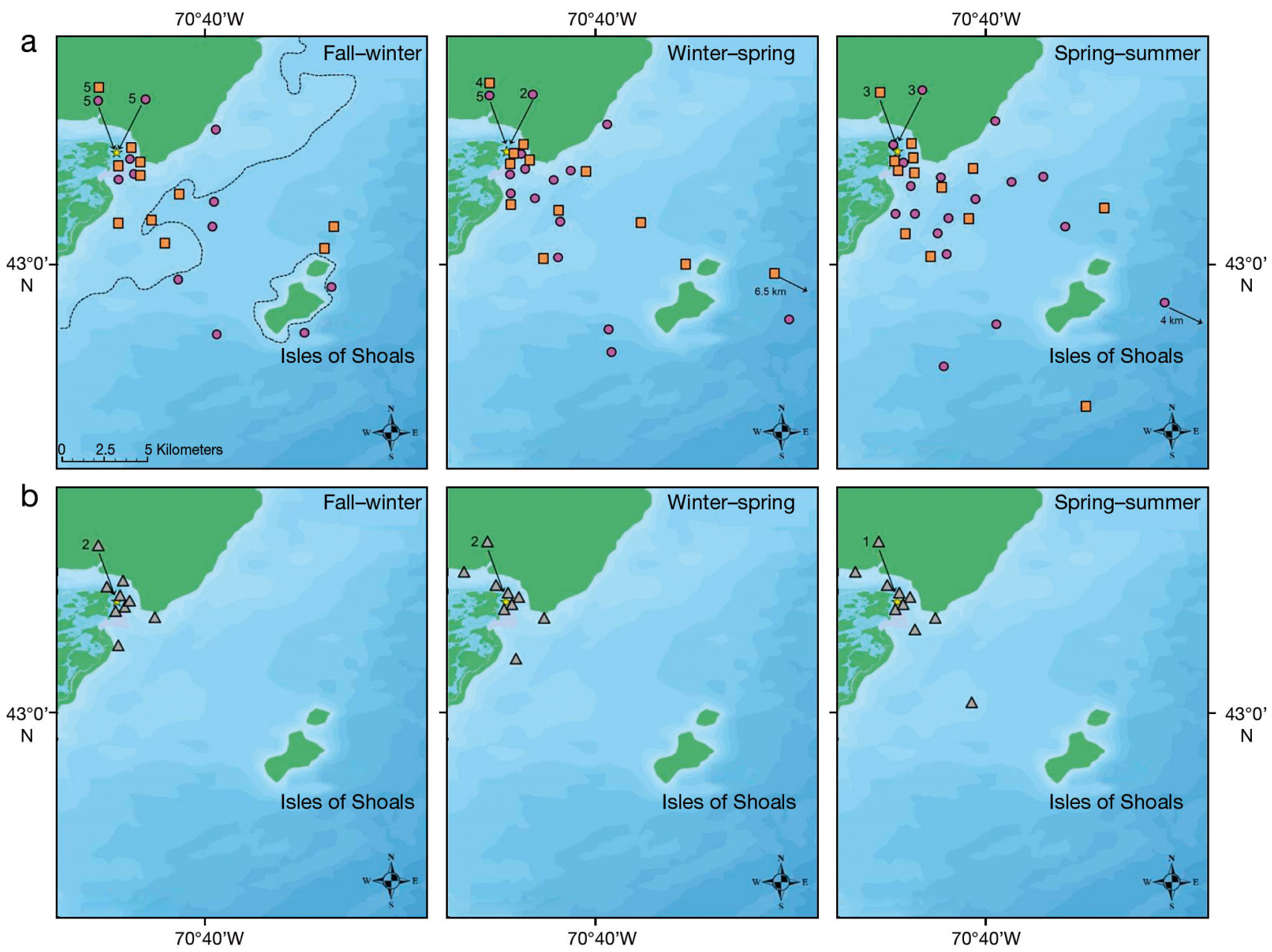

Fig. 8. Homarus americanus. Seasonal movements of (a) female lobsters (ovigerous, $\mathrm{n}=20$, circles; non-ovigerous, $\mathrm{n}=15$, squares), and (b) male lobsters ( $\mathrm{n}=10$, triangles) during the fall-winter, winter-spring and spring-summer time periods (see 'Materials and methods' for definitions). Numbers adjacent to symbols indicate multiple lobsters (n) at that location. Other details as in Fig. 1

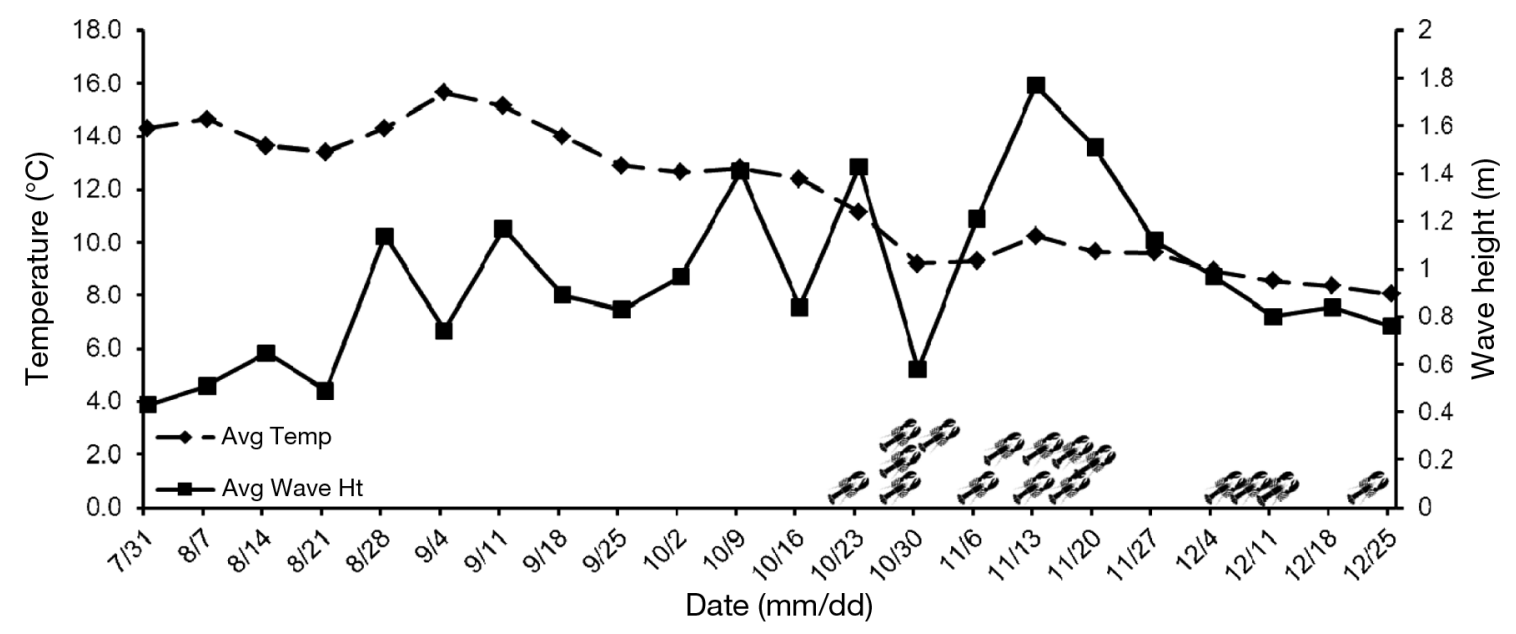

Fig. 9. Weekly water temperatures and wave heights in the fall of 2006 for the period before and during the offshore movements of tagged lobsters Homarus americanus. Lobster symbols indicate when individual lobsters initiated offshore movements. Most $(75 \%, \mathrm{n}=16)$ of the lobsters left the area between October 22 and November 21, with a mean date of departure of 
where seasonal movements and overall activity patterns also correlated with seasonal fluctuations in water temperature (Moland et al. 2011).

Most attention on the relationship between water temperature and seasonal movements in American lobsters has focused on ovigerous females because their movements influence the thermal history of the eggs they carry for 9-11 mo (Templeman 1940, Cowan et al. 2007). Seasonal inshore-to-offshore movements of ovigerous lobsters optimize the number of degree-days for rapid egg development (Campbell 1986). However, we recently demonstrated no significant difference in the number of degree-days accumulated by lobsters inhabiting inshore vs. offshore waters in coastal New Hampshire waters (Goldstein 2012). Note, however, that differences between inshore and offshore water temperatures might be more pronounced in some regions (e.g. Atlantic Canada, Gendron \& Ouellet 2009), and thus ovigerous female movements in these areas may be vital for providing eggs with sufficient degree-days so that they hatch at an appropriate time. Waddy \& Aiken (1995) demonstrated that lobster egg development slowed at temperatures $<4^{\circ} \mathrm{C}$ and hypothesized that eggs exposed to a sufficient number of days less than this threshold value would be synchronized for summer hatching. Overall, we found no difference between inshore and offshore seawater temperatures ( $p=0.440, t$-test) over the course of the year. However, water temperatures for inshore and offshore differed significantly within the May-August (springsummer) time period, $\left(11.5^{\circ} \mathrm{C}\right.$ vs. $10.5^{\circ} \mathrm{C}$; $t$-test, $\mathrm{p}=$ 0.011 , respectively). Data provided from a complementary study, emphasize the importance of differing thermal regimes on developing eggs and suggest that the rapid rate of warming of inshore waters in the spring profoundly impacts the time of larval hatch in these locations (Goldstein \& Watson 2015).

\section{Seasonal movement patterns}

The data obtained in this study contradict the hypothesis that ovigerous females move offshore in the fall and then return inshore to incubate their eggs in warmer water in the spring and early summer. Because one of our main goals was to track females through until egg hatch, and noting the finite battery life of each tag, we were unable to evaluate a full year of movement for all females, something that could be evaluated in future studies. Although we did not track individual lobsters throughout an entire year, it is possible that the lobsters we tracked re- turned to inshore waters later in the summer after our tags stopped transmitting. That said, with the timing of egg development at different temperatures, we can say confidently that many $(\sim 50 \%, \mathrm{n}=10)$ of the ovigerous lobsters we tracked remained offshore until after their eggs hatched in the summer (Fig. 8) and, in some cases, these animals only undertook large excursions after their expected time of egg hatching (e.g. Fig. 7). Two previous studies reported similar data; Jarvis (1989) documented strong resident behavior in late-stage ovigerous lobsters, and both Jarvis (1989) and Watson et al. (1999) reported little movement in females with late-stage eggs compared to other females. Moreover, females in both studies appeared to increase in mobility after the time when their eggs likely hatched. Because ovigerous females remained offshore until after their eggs hatched, larvae were presumably released offshore rather than inshore locations. Ongoing ocean drifter and drogue trials indicate different likely trajectories in larvae released offshore than those that hatch inshore (Goldstein 2012). Thus, at least in NH and southern Gulf of Maine coastal waters, larvae dispersed from offshore locales increases the probability of settlement in a variety of different areas (Incze et al. 2010).

One goal of this study was to ascertain whether seasonal movement patterns of ovigerous American lobsters differed from their male or non-ovigerous female counterparts. We found disproportionately longer movements by ovigerous and non-ovigerous females $(60 \%$ moved $>5 \mathrm{~km})$ compared with males (no male moved $>4 \mathrm{~km}$ ). Many studies attribute sexbiased movements to selective pressures acting on disparate male and female reproductive strategies or physiological requirements (Haakonsen \& Auoruo 1994, Jury et al. 1994, Jury \& Watson 2013). For example, male American lobsters can withstand lower salinities and prefer warmer water, which may explain their prevalence in the upper reaches of bays and estuaries (Munro \& Thierriault 1983, Howell et al. 1999, Jury \& Watson 2013). Past studies document differences in movement patterns in coastal male and female lobsters, but the patterns are not as clear as those shown in the present study. Campbell \& Stasko (1986) and Templeman (1940) found greater distances moved by mature females than mature males in some areas, but not others, whereas ovigerous females in waters near Cape Cod, Massachusetts moved farther and faster than other lobsters (Morrissey 1971). Fogarty et al. (1980) and Krouse (1981) found no differences in the movements of male and female lobsters, possibly because many of the lobsters they tracked 
were immature. Whereas constraints of reproduction may strongly influence movements in female lobsters, territorial male lobsters defend dens, especially during the mating season (Karnofsky et al. 1989). Therefore, males may move less than females, especially during certain times of year (e.g. molting, den acquisition). Because we followed all types of American lobsters throughout most of the year, including during their breeding season, mating-related behaviors, including the defense of dens, may have driven some differences in male and female movement. This interpretation is consistent with reduced movements of large males in a high-resolution telemetry study conducted in the same location as our study (Golet et al. 2006). However, because we tagged and released our lobsters in late summer and early fall after most lobsters had already mated, and we tracked them until the beginning of the mating season in the following year, it is unlikely that the inshore residency of males in this study was solely the result of guarding potential mating dens. Although our goal was to track as many kinds of American lobsters as possible, time and financial constraints limited our statistical power given the variability in movement, a problem encountered by many telemetry studies (Pittman \& McAlpine 2003). Nonetheless, the detailed telemetry tracks provide important information on individual movements (a key contribution to this study) and continued technological improvements will further enhance future studies.

\section{Foraging-related movements}

Although we found that female lobsters tended to move most, the fact that both large and small lobsters tended to move offshore in the fall and, to a lesser extent, inshore in the spring, suggests that needs common to most lobsters motivated these seasonal movements. As key predatory species, American lobsters exert a strong influence on their ecosystem by foraging on benthic communities (Scarratt 1980, Conklin 1995, Palma et al. 1998). On a daily basis, foraging activity probably accounts for many of the documented small, local movements (typically 100-500 m or less; Cooper \& Uzmann 1971, Ennis 1984, Scopel et al. 2009). However, even though these animals do not move very far during their daily foraging excursions, their larger seasonal movements may be motivated, in part, by a need to move to areas of high prey abundance during the time of year when they are most active and require the most nutrition. Despite no direct evidence that food availability drives inshore movements of lobsters, they often shift their prey base spatio-temporally and this may drive some seasonal movement patterns (Scarratt 1980, Elner \& Campbell 1987).

\section{Environmental perturbations}

The cues that initiate and control seasonal, directed movements in American lobsters are largely unknown. Movements typically correlate with seasonal changes in temperature and, in locations such as estuaries, fluctuations in salinity (Wahle 1993, Jury et al. 1995, Watson et al. 1999). However, Cooper et al. (1975) reported that these lobsters typically moved from shoal waters $(5-20 \mathrm{~m})$ to deeper waters $(30-60 \mathrm{~m})$ during strong wind events associated with increased wave heights. Others report that a combination of ice scour and wave action reaching shallow bottom sediments (coupled with low water temperatures) triggered lobsters to shelter beneath hard substrate features or in deep water (Ennis 1984, Karnofsky et al. 1989). Some of the strongest correlations between seasonal lobster movements and environmental perturbations come from studies on the Caribbean spiny lobster Panulirus argus, where autumnal storms (with associated increases in waves and turbidity), coupled with decreasing water temperatures of $\sim 5^{\circ} \mathrm{C}$ over several days, appear to trigger mass migration (Kanciruk \& Herrnkind 1978, Herrnkind 1980). In contrast, other cues such as day length, photoperiod, and changes in salinity were generally insufficient to elicit the same responses in other lobsters (e.g. Panulirus ornatus, Moore \& MacFarlane 1984).

Our study correlated the offshore movements of tagged lobsters in the fall with decreasing water temperatures and increased wave action due to storms, a finding consistent with several aforementioned models. Although American lobsters often undertake large post-tagging, post-handling movements, this phenomenon cannot explain our results. Most of the lobsters used for our study were resident near the tagging location for about a month prior to their seasonal offshore excursions (VRAP telemetry data). Interestingly, in a parallel and concurrent study in the nearby Great Bay Estuary, fewer lobsters moved in the fall than those tagged along the coast (T. Langley et al. unpubl. data.). We believe this difference may be explained by drops in water temperature experienced by lobsters in the estuary that were as pronounced as those encountered by lobsters along the coast, but without exposure to the same large wave events. Therefore, our results support the hypothesis that seasonal offshore movements of American lob- 
sters are triggered by a combination of falling temperatures and other environmental stimuli (such as storm events) that create a more challenging and stressful environment in inshore areas. However, we acknowledge that other environmental cues could be equally important, or work in synergy with these cues to trigger or direct the offshore movements of lobsters in the fall. Logically, a series of lab-based trials may provide the best opportunity to isolate the most potential environmental cues.

\section{Brooding-related movements}

Many ovigerous marine crustaceans (e.g. spiny lobsters and crabs) that maintain external lecithotrophic egg masses and hatch pelagic larvae undergo brooding-related movements that are thought to selectively position larvae for transport away from unfavorable environments. Booth (1997) summarized long-distance movement data for several Pacific spiny lobsters and associated inshore-to-offshore movement events with reproduction and molting. Other such lobster movements are described as contranatant, acting to facilitate dispersal of larvae to maternal areas (e.g. Groeneveld \& Branch 2002). Telemetry studies of the movements of late-stage ovigerous Caribbean spiny lobsters Panulirus argus determined that some individuals leave their dens to release their larvae at the reef edge and then return (Bertelsen \& Hornbeck 2009, Bertelsen 2013). One of the most interesting spawning migrations occurs in ornate spiny lobsters Panulirus ornatus, where females undertake mass migrations (maximum distance $=511 \mathrm{~km}$ ) across the Gulf of Papua (Moore \& MacFarlane 1984). Although there is clear evidence that some ovigerous lobsters incorporate broodingspecific movements into their repertoire to optimize larval release, whether ovigerous American lobster females make such directed movements solely for this purpose remains unclear. Most ovigerous females tagged in our study (80\%) remained offshore throughout much of the egg development period until their eggs hatched. However, other ovigerous females $(35 \%)$ moved $<2 \mathrm{~km}$ or remained resident near the tagging location. Perhaps the advantages of releasing larvae offshore drive behavior of ovigerous lobsters in this region more than gaining degreedays by moving back inshore in the spring, whereas movement back inshore in the spring in other regions may be necessary in order to accelerate egg development and ensure that eggs hatch at the appropriate time of year.

\section{Implications for larval dispersal}

Because local oceanographic conditions (e.g. tidal fronts, eddies, convergence zones) often constrain larval dispersal, the location (inshore vs. offshore) of ovigerous lobsters over their hatching period can significantly influence larval dispersal and, ultimately, survival. Even modest movements by brooding adults $(10 \mathrm{~s}$ of $\mathrm{km})$ can significantly impact subsequent larval trajectories. This effect has been demonstrated in other marine species with meroplanktonic larvae, particularly marine fishes that sometimes self-recruit to natal locations (e.g. Almany et al. 2007). Therefore, knowledge of the movements of ovigerous lobsters, and their locations during hatching, could enhance our understanding of larval dispersal and help to refine existing biophysical models of connectivity for $H$. americanus (Harding et al. 2005, Xue et al. 2008, Incze et al. 2010). These data also have biologically relevant implications for future studies and MPA design for $H$. americanus stocks across its range from Atlantic Canada to Southern New England.

Lobsters are highly mobile and their attraction to specific temperatures, and avoidance of others, greatly impacts their seasonal movements and distribution (Childress \& Jury 2006). As climate change warms shallow, coastal waters, lobsters will likely adjust their movements to remain within their preferred temperature range (thermal niche), and vacate other areas (Caputi et al. 2013). In the case of NH coastal lobsters, this preference may drive offshore movement into deeper water, as reported in the southern extent of their range (Buzzard's Bay, Massachusetts, T. Pugh \& R. Glenn unpubl. data). This behaviour, in turn, could shift the timing and location of hatch, which would invariably influence larval drift and recruitment, as well as overall population dynamics. Therefore, scientists and fisheries managers alike must consider the potential impact of climate change on seasonal movements of ovigerous lobsters and devise appropriate management strategies to ensure the long-term health and sustainability of this highly lucrative fishery.

Acknowledgements. Project interns (May Grose, Sarah Havener, Joy Strunk and Haley White) were integral to the long-term management and success of this field-intensive project. Special thanks to Darren Scopel, Chris Rillahan, Thomas Langley and Liz Kintzing for assistance with SCUBA surveys and help trouble-shooting the telemetry systems. Rebecca Kibler helped with several iterations of the figures and text and improved them substantially. J. A. Bolker gave helpful and constructive editorial comments to 
the manuscript. A special thanks to J. Callwood for his artistic rendering of Fig. 2. The authors also extend their gratitude to all the New Hampshire (NH) and Maine lobstermen who cooperated in the recapture and reporting of animals throughout the study, and added many helpful comments for discussion. Funding for this project was provided by multiple sources including a Northeast Consortium (NOAA) Grant (\# 111856) to W.H.W., a NH Sea Grant (project \# R/MED-9) to W.H.W. and J.S.G. and a University of New Hampshire Marine Program Grant to J.S.G. The authors claim no conflict of interest with AMIRIX (VEMCO) Systems Inc. or any of its products.

\section{LITERATURE CITED}

Almany GR, Berumen ML, Thorrold SR, Planes S, Jones GP (2007) Local replenishment of coral reef fish populations in a marine reserve. Science 316:742-744

Annis ER, Incze LS, Wolff N, Steneck RS (2007) Estimates of in situ larval development time for the lobster, Homarus americanus. J Crustac Biol 27:454-462

- Bertelsen RD (2013) Characterizing daily movements, nomadic movements, and reproductive migrations of Panulirus argus around the Western Sambo ecological reserve (Florida, USA) using acoustic telemetry. Fish Res 144:91-102

Bertelsen RD, Hornbeck J (2009) Using acoustic tagging to determine adult spiny lobster (Panulirus argus) movement patterns in the Western Sambo Ecological Reserve (Florida, United States). NZ J Mar Freshw Res 43:35-46

Booth JD (1997) Long-distance movements in Jasus spp. and their role in larval recruitment. Bull Mar Sci 61:111-128

> Bowlby HD, Hanson JM, Hutchings JA (2007) Resident and dispersal behavior among individuals within a population of American lobster Homarus americanus. Mar Ecol Prog Ser 331:207-218

Bowler DE, Benton TG (2005) Causes and consequences of animal dispersal strategies: relating individual behavior to spatial dynamics. Biol Rev Camb Philos Soc 80: 205-225

Campbell A (1986) Migratory movements of ovigerous lobster, Homarus americanus, tagged off Grand Manan, eastern Canada. Can J Fish Aquat Sci 43:2197-2205

Campbell A, Stasko AB (1986) Movements of lobsters (Homarus americanus) tagged in the Bay of Fundy, Canada. Mar Biol 92:393-404

Caputi N, de Lestang S, Frusher S, Wahle RA (2013) The impact of climate change on exploited lobster stocks. In: Phillips BF (ed) Lobsters: biology, management, aquaculture, and fisheries, 2nd edn. John Wiley \& Sons, Oxford, p 129-168

Childress MJ, Jury SH (2006) Behaviour. In: Phillips BF (ed) The biology of lobsters. Blackwell Publishing, Oxford, p 78-112

Conklin DE (1995) Digestive physiology and nutrition. In: Factor JR (ed) Biology of the lobster Homarus americanus. Academic Press, San Diego, CA, p 153-175

> Cooper RA, Uzmann JR (1971) Migrations and growth of deep-sea lobsters, Homarus americanus. Science 171: 288-290

Cooper RA, Uzmann JR (1980) Ecology of juvenile and adult Homarus. In: Cobb JS, Phillips BF (eds) The biology and management of lobsters. Academic Press, New York, NY, p 97-142

> Cooper RA, Clifford RA, Newell CD (1975) Seasonal abundance of the American lobster, Homarus americanus in the Boothbay Region of Maine. Trans Am Fish Soc 104: 669-674

Cowan DF, Watson WH III, Solow AR, Mountcastle AM (2007) Thermal histories of brooding lobsters, Homarus americanus, in the Gulf of Maine. J Mar Biol 179:70-78

$>$ Crossin GT, Al-Ayoub SA, Jury SH, Howell WH, Watson WH III (1998) Behavioral thermoregulation in the American lobster Homarus americanus. J Exp Biol 201:365-374

> Dufort CG, Jury SH, Newcomb JM, O'Grady DF, Watson WH III (2001) Detection of salinity by the lobster, Homarus americanus. Biol Bull 201:424-434

> Elner RW, Campbell A (1987) Natural diets of lobster Homarus americanus from barren ground and macroalgal habitats off southwestern Nova Scotia, Canada. Mar Ecol Prog Ser 37:131-140

- Ennis GP (1984) Small-scale seasonal movements of the American lobster Homarus americanus. Trans Am Fish Soc 113:336-338

Fogarty MJ, Borden DVD, Russell HJ (1980) Movements of tagged American lobster Homarus americanus, off Rhode Island. Fish Bull 78:771-780

> Gendron L, Ouellet P (2009) Egg development trajectories of early and late-spawner lobsters (Homarus americanus) in the Magdalen Islands, Quebec. J Crustac Biol 29: 356-363

Goldstein JS (2012) The impact of seasonal movements by ovigerous American lobsters (Homarus americanus) on egg development and larval release. PhD dissertation, University of New Hampshire, Durham, NH

Goldstein JS, Watson WH III (2015) Quantifying the influence of natural inshore and offshore thermal regimes on egg development in the North American lobster, Homarus americanus. Biol Bull 228:1-12

> Golet WJ, Scopel DA, Cooper AB, Watson WH III (2006) Daily patterns of locomotion expressed by American lobsters (Homarus americanus) in their natural habitat. J Crustac Biol 26:610-620

> Gonzalez-Gurriaran E, Freire J, Bernardez C (2002) Migratory patterns of female spider crabs Maja squinado detected using electronic tags and telemetry. J Crustac Biol 22:91-97

Groeneveld JC, Branch GM (2002) Long-distance migration of South African deep-water rock lobster Palinurus gilchristi. Mar Ecol Prog Ser 232:225-238

Haakonsen HO, Anoruo AO (1994) Tagging and migration of the American lobster Homarus americanus. Rev Fish Sci 2:79-93

Harding GC, Trites RW (1988) Dispersal of Homarus americanus larvae in the Gulf of Maine from Browns Bank. Can J Fish Aquat Sci 45:416-425

Harding GC, Drinkwater KF, Hannah CG, Pringle JD and others (2005) Larval lobster (Homarus americanus) distribution and drift in the vicinity of the Gulf of Maine offshore banks and their probable origins. Fish Oceanogr 14:112-137

Helluy S, Beltz BS (1991) Embryonic development of the American lobster Homarus americanus: quantitative staging and characterization of an embryonic molt cycle. Biol Bull 180:355-371

Herrnkind WF (1980) Spiny lobsters: patterns of movement. In: Cobb JS, Phillips BF (eds) The biology and management of lobsters, Vol I. Academic Press, New York, NY, p 349-407

Howell WH, Watson WH III, Jury SH (1999) Skewed sex ratio in an estuarine lobster (Homarus americanus) population. J Shellfish Res 18:193-201

Incze L, Xue H, Wolff N, Xu D and others (2010) Connectiv- 
ity of lobster (Homarus americanus) populations in the coastal Gulf of Maine: Part II. Coupled biophysical dynamics. Fish Oceanogr 19:1-20

Jarvis C (1989) Movement patterns of late-stage ovigerous female lobsters (Homarus americanus Milne-Edwards) at Jeddore, Nova Scotia. MS thesis, Dalhousie University, Halifax

Jepsen N, Koed A, Thorstad E, Baras E (2002) Surgical implantation of telemetry transmitters in fish: How much have we learned? Hydrobiologia 483:239-248

Jury SH, Watson WH III (2000) Thermosensitivity of the lobster, Homarus americanus, as determined by cardiac assay. Biol Bull 199:257-264

> Jury SH, Watson WH III (2013) Seasonal and sexual differences in the thermal preferences and movements of American lobsters. Can J Fish Aquat Sci 70:1650-1657

Jury SH, Kinnison MT, Howell WH, Watson WH III (1994) The effects of reduced salinity on lobster (Homarus americanus Milne-Edwards) metabolism: implications for estuarine populations. J Exp Mar Biol Ecol 176:167-185

Jury SH, Howell WH, Watson WH III (1995) Lobster movements in response to a hurricane. Mar Ecol Prog Ser 119: 305-310

Kanciruk P, Herrnkind WF (1978) Mass migration of spiny lobster, Panulirus argus (Crustacea: Palinuridae): population dynamics, environmental correlates and triggering stimuli. Bull Mar Sci 28:601-623

Karnofsky EB, Atema J, Elgin RA (1989) Field observations of social behavior, shelter use, and foraging in the lobster, Homarus americanus. Biol Bull 176:239-246

Krouse JS (1981) Movements, growth and mortality of American lobster, Homarus americanus, tagged along the coast of Maine. NOAA Tech Rep NMFS-RF 747

Lawton P, Lavalli KL (1995) Postlarval, juvenile, adolescent, and adult ecology. In: Factor JR (ed) Biology of the lobster Homarus americanus. Academic Press, San Diego, CA, p 47-81

Little SA, Watson WH III (2003) Size at maturity of female American lobsters from an estuarine and coastal population. J Shell Res 22:857-863

> MacKenzie BR (1988) Assessment of temperature effect on interrelationships between stage durations, mortality, and growth in laboratory-reared Homarus americanus Milne Edwards larvae. J Exp Mar Biol Ecol 116:87-98

Moland E, Olsen EM, Knutsen H, Knutsen JA, Enersen SE, Andre C, Stenseth NC (2011) Activity patterns of wild European lobster Homarus gammarus in coastal marine reserves: implications for future reserve design. Mar Ecol Prog Ser 429:197-207

> Moore R, MacFarlane JW (1984) Migration of the ornate rock lobster, Panulirus ornatus (Fabricius), in Papua New Guinea. Aust J Mar Freshw Res 35:197-212

Morrissey TD (1971) Movements of tagged American lobsters, Homarus americanus liberated off Cape Cod, Massachusetts. Trans Am Fish Soc 100:117-120

Munro J, Therriault JC (1983) Migrations saisonnières du homard (Homarus americanus) entre la côte les lagunes des Îles-de-la-Madeleine. Can J Fish Aquat Sci 40: 905-918

Nathan R (2008) An emerging movement ecology paradigm. Proc Natl Acad Sci USA 105:19050-19051

Editorial responsibility: Paul Snelgrove, St. John's, Newfoundland and Labrador, Canada
Palma AT, Wahle RA, Steneck RS (1998) Different early post-settlement strategies between American lobsters Homarus americanus and rock crabs Cancer irroratus in the Gulf of Maine. Mar Ecol Prog Ser 162:215-225

Perkins H (1972) Developmental rates at various temperatures of embryos of the northern lobster (Homarus americanus Milne Edwards). Fish Bull 70:95-99

Pittman SJ, McAlpine CA (2003) Movements of marine fish and decapod crustaceans: process, theory and application. Adv Mar Biol 44:205-294

Reynolds WW, Casterlin ME (1979) Behavioral thermoregulation and activity in Homarus americanus. Comp Biochem Physiol 64:25-28

Robichaud DA, Campbell A (1995) Movement, reproduction and growth of ovigerous lobsters (Homarus americanus) from Newfoundland released off Grand Manan, Bay of Fundy. J Shellfish Res 14:199-204

Scarratt DJ (1980) The food of lobsters. Can Tech Rep Fish Aquat Sci 954:66-91

Scopel DA, Golet W, Watson WH III (2009) Home range dynamics of the American lobster, Homarus americanus. Mar Freshw Behav Physiol 42:63-80

Spanier E, Tom M, Pisanty S, Almog G (1988) Seasonality and shelter selection by the slipper lobster Scyllarides latus in the southeastern Mediterranean. Mar Ecol Prog Ser 42:247-255

> Stone RP, O'Clair CE (2002) Behavior of female Dungeness crabs, Cancer magister, in a glacial southeast Alaska estuary: homing, brooding-site fidelity, seasonal movements, and habitat use. J Crustac Biol 22:481-492

Talbot P, Helluy S (1995) Reproduction and embryonic development. In: Factor JR (ed) Biology of the lobster Homarus americanus. Academic Press, San Diego, CA, p $177-216$

Templeman W (1940) Embryonic development rates and egg laying of Canadian lobsters. J Fish Res Board Can 5a:71-83

> Waddy SL, Aiken DE (1992) Environmental intervention in the reproductive process of the American lobster, Homarus americanus. Invertebr Rep Dev 22:245-251

Waddy SL, Aiken DE (1995) Temperature regulation of reproduction in female American lobsters, Homarus americanus. ICES Mar Sci Symp 199:54-60

Wahle RA (1993) Recruitment to American lobster populations along an estuarine gradient. Estuaries 16:731-738

Watson WH III, Chabot CC (2010) High resolution tracking of adult horseshoe crabs Limulus polyphemus in a New Hampshire estuary using a fixed array ultrasonic telemetry. Curr Zool 56:599-610

Watson WH III, Vetrovs A, Howell WH (1999) Lobster movements in an estuary. Mar Biol 134:65-75

Webber D (2009) VEMCO acoustic telemetry: new user guide. AMIRIX Systems, DOC-004934-01, VEMCO, Halifax

> Worden MK, Clark CM, Conway M, Qadri SA (2006) Temperature dependence of caridac performance in the lobster Homarus americanus. J Exp Biol 209:1024-1034

> Xue H, Incze L, Xu D, Wolff N, Pettigrew N (2008) Connectivity of lobster populations in the coastal Gulf of Maine. Part I: Circulation and larval transport potential. Ecol Modell 210:193-211

Submitted: December 27, 2013; Accepted: January 7, 2015

Proofs received from author(s): March 11, 2015 